\title{
Shin Buddhist Perspectives on Buddha-Nature:
}

Challenges in the Dimensions of Personal Subjectivity and Societal Aspect in Religious Pluralism

\author{
FujIWARA Wondra Mutsumi
}

\section{Introduction}

This paper presents how the unique Shin Buddhist perspectives of Buddha-nature influence our personal subjectivity and societal aspect in the relationship with Buddha-Dharma's wisdom. First, I will overview various understandings of Buddha-nature among the past Shin sectarian scholars during the 17 th to early 20 th centuries. Second, by referring to the comments by contemporary Shin scholars including in the West, some controversial issues to the current understanding of Buddha-nature will be explored in Shin Buddhism doctrine. Third, I will examine challenges from the perspectives of Buddha-nature in the relationship with directed Other-Power, when facing the issues of personal subjectivity and societal aspect in the religious pluralistic and multi-cultural contemporary society where we live.

\section{Shinran's Approach on Buddha-Nature}

Shinran 親鸞 provides little explanation or theoretical analysis about Buddha-nature, instead quotes passages from the Nirvana Sutra. He equates Buddha-nature with shinjin 信 心 ${ }^{1)}$ for two reasons: (1) It means that one entrusts in the Vow of the Amida; and (2) shinjin is the aspiration to bring all beings to the attainment of supreme nirvana (supreme enlightenment). But, questions remain. Why do beings have the potential for enlightenment? It is because all beings possess the potential for Buddhahood? Or, is it because Buddha-nature pervades all things? Are all causes including even the potential to receive the Name bestowed from the Amida as the directed virtue, called Other-Power, because of no possibility of human beings to attain Buddhahood? What is the relationship between Buddha-nature and Other-Power? 


\section{Overview of Shin Buddhist Perspectives on Buddha-Nature by Sectarian Scholars}

Shin traditional sectarian scholars during the 17 th to early 20 th centuries developed approximately five different theories pertaining to Buddha-nature, as the below diagram shows. It is interesting to note that the debate over Buddha-nature among sectarian scholars broke down along traditional school lines. For instance, the School of Sekisen 石泉 thought is that all beings are essentially possessed of potential for Buddhahood (Buddha-nature). They basically affirmed the Nirvana Sutra teaching that Buddha-nature exists fundamentally within beings. In contrast, School of Kūge 空華 and Buzen 豊前 viewed that Buddhanature completely pervades all things, based on some of Shinran's passages. They held basically that Amida's activity fills the ten quarters, thus entering the hearts of sentient beings and bestowing the potential for enlightenment upon them. Those holding that "all beings possess Buddha-nature" were to be found among those who saw value in human practice and will. On the other side, those finding that "Buddha-nature completely pervades all things" tended to point to the solitary working of the Vow and Name.

Another issue that was hotly debated by sectarians was, "How should we reconcile the notion of Buddha-nature with the notion of Other-Power?" It has been asked, if sentient beings essentially possess Buddha-nature, which is the cause of enlightenment, then doesn't Other-Power merely become a secondary condition? Orthodoxy states that the true cause of birth is the sole working of the Buddha alone, that is, absolute Other-Power in the form of Vow, Name and shinjin. In this case, the potential of Buddha-nature would not turn Other-Power into a secondary condition. On the other hand, if sentient beings do not possess Buddha-nature as a cause, how would we expect the effect (Buddhahood) arising without a cause (no potential)? This would violate the basic Buddhist law of karma. Without Buddha-nature as a cause, the resultant state of Buddhahood could not arise, and even with the activity of Other-Power, sentient beings would have no possibility of attaining Buddhahood. The current theory of Buddha-nature in Shin Buddhism doctrine, led by Kūge School, explains that all causes including even the potential to receive the Name are granted from the Amida, because Shinran states that shinjin is identical with Buddha-nature. The problem in this theory is to negate even innate potential in human beings to receive the Name. 


\section{Shin Sectarian Scholars and School Lineage ${ }^{2)}$}

(Nōke \# 1) (Nōke \#2) (Nōke\#3) (Nōke \#4)

Saigin 西吟一 (Chikū 知空) 一Jakurin 若霖一Hōrin 法霖一Sōboku 僧樸

1605-1663 1634-1718 1675-1735 1693-1741 1719-1762

Affirmation of Innate Potential for Buddhahood

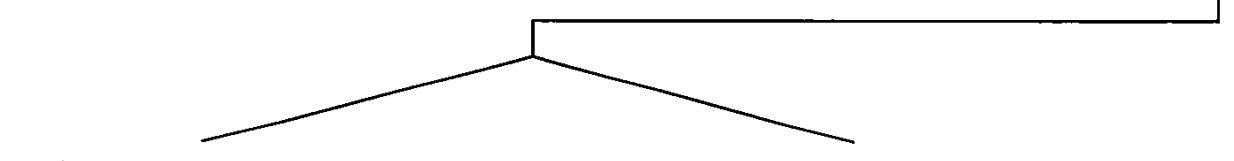

(Eun 慧雲)

1730-1782

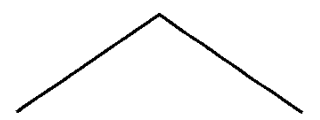

$\langle$ Seien School 〈Sekisen School 芿園学派〉

(Daiei 大蜲)

1759-1804

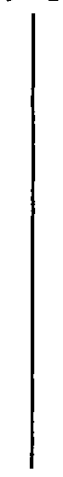

Dōshin 道振

1773-1824

Non-self-nature Buddha-nature

1798-1854

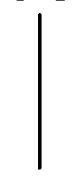

Gizan 義山

$1824-1910$
Sōyō 僧鎔 〈Kūge School 空華学派〉

1723-1783 Theory of Buddha-nature

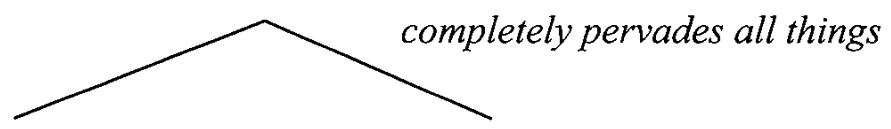

〈Sakai Kūge 堺空華〉

Dōon 道隠

越中空華〉

Nyūon 柔遠

1742-1798

Buddha-nature

with Shinjin

(Gyōshō 行照)

1795-1862

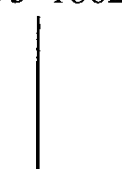

Senmyō 鮮妙

1835-1914

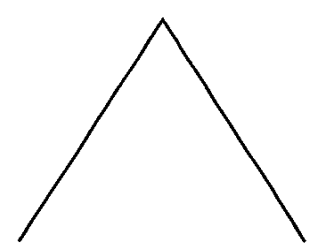

(Shōkai 性海) 1765-1838

Zenjō 善譲

Engetsu 円月

1818-1902

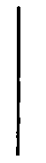

Gesshu 月珠

$\langle$ Buzen School

豊前学派〉

$-1856$

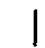

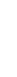

Completed the theory of Buddha-nature

Completely pervades all things. 
from the Christian anthropology started from the Genesis. Buddhism is radically cosmocentric, versus anthropocentric in Christian theology. ${ }^{4)}$ Taitetsu Unno, one of the Shin scholars in the U.S. points out the stress on absolute Other-Power in the orthodox Shin teaching, and Shin Buddhism today has become an authoritarian religion, rejecting all forms of independent thinking and questioning. Since the orthodox Shin teaching has stressed the working of absolute Other-Power exclusively, any exploration of the individual to attain such awareness has been rejected as a self-power deviation. ${ }^{5)}$ The relationship of Buddha-nature and Other-Power is the important issue not only within the doctrinal issue, but also influences the notion of personal subjectivity and societal aspects in the contemporary society of religious pluralism. Personal subjectivity refers to the deepest level of the self, which must be experienced individually and realized profoundly. Societal aspects refer to having involvement with others and societal issues in the society where we live.

\section{Conclusions-Possibilities of Reinterpretation}

Here I will explore the possibilities of reinterpreting the current notion of Buddha-nature and Other-Power in Shin Buddhism doctrine, which is more consonant with personal subjectivity and societal aspects in religious pluralism. In order to maintain Shinran's statement that the true essence of the Pure Land way is the consummation of Mahayana Buddhism, ${ }^{6}$ ) the innate potential to receive the Name within human beings should be allowed in the current theory of Buddha-nature with shinjin. Shinran explained "Other-Power is none other than the power of the Tathagata's Primal Vow."7) Other-Power that is the power beyond self refers to the dynamic movement of religious life in order to enable us to realize shortcoming and foolish notions of the self, and objectified notions of the other which are held by ignorant beings. It can be said that the notion of shinjin is the experience of "otherness." For Shinran, the awakening of shinjin, which arise not through one's own calculation, but through the working of Other-Power of Amida's Vow, is nothing other than the arising of wisdom itself. This means that each human being will find the way that he or she lives a true life, sustained by the Primal Vow. Establishing each personal subjectivity in the light of wisdom expands in a lateral way to care others and society with compassion where we live. ${ }^{8)}$ By hearing and receiving the meaning of the Name without any doubt, the issue of one's salvation (establishing a personal subjectivity) inevitably develops another dimension of societal aspects (salvation of others and society). Those constant ripples never 
stop. In this sense, Shinran's perspective on entering the wisdom of shinjin cannot be separated from the societal dimension of human life.

1) CWS, p. 99, JSZ, p. 84, CP, p. 236; Great shinjin is none other than Buddha-nature. CWS, p. 463, JSZ, pp. 707-707, CP, p. 712; This shinjin is Buddha-nature.

2) Murakami Sokusui 村上速水, Shinsh̄̄ kyōgaku shi ni okeru busshō rongi no kaiko to mondaiten: Zoku Shinran kyōgi no kenkyu 真宗教学史における仏性論議の回顧と問題点: 続親㝈教義の研 究 (Kyoto: Nagata Bunshōdō, 1989), pp. 168-169.

3 ) Kenryu Tsuji, The Heart of the Buddha-Dharma (Berkeley, California: Ekoji Buddhist Temple and Numata Center for Buddhist Translation and Research, 2003), p. 11.

4 ) Masao Abe, Man and Nature in Christianity and Buddhism: The Buddha Eye, edited by Frederick Franck (New York: World Wisdoms, 2004), p. 153.

5 ) Taitetsu Unno, Shin Buddhism in the West: The Question of Authenticity; Engaged Pure Land Buddhism (Berkeley, California: Wisdom Ocean Publication, 1998), pp. 8-9.

6 ) CWS, p. 524, CP, p. 737.

7 ) CWS, p. 57, CP, p. 190.

8 ) CWS, p. 551, JSZ, p. 809, CP, p. 742; CWS, p. 560, JSZ, p. 830, CP, p. 784.

\section{〈Abbreviations of References〉}

SSZ Shinshū shōgyō zensho 真宗聖教全書. Volume 2, Shūso-bu 宗祖部.

ST Jōdo Shinshū seiten zensho 浄土真宗聖典全書. Volume 2, Shūso-hen 宗祖篇, jō 上.

CP Jōdo Shinshū seiten chūshaku-ban 浄土真宗聖典 註䣋版.

CWS The Collected Works of Shinran. Volume I, The Writings. Shin Buddhism Translation Series. Kyoto: Jodo Shinshu Hongwanji-ha, 1997.

〈Key words〉 contextualization, religious pluralism, Buddha-nature, Shin Buddhism in North America (Graduate Student, Ryukoku University) 